\title{
PEMANFAATAN HASIL FERMENTASI LIMBAH CAIR TEH HIJAU PADA FREKUENSI PENYIRAMAN YANG BERBEDA TERHADAP PERTUMBUHAN BIBIT KARET (Hevea brasiliensis Mull. Arg)
}

\author{
Retno Muningsih ${ }^{1}$ dan Farhan Wardhana Majing ${ }^{1}$ \\ ${ }^{1}$ Politeknik LPP Yogyakarta \\ Email koresponden: retnomuningsih@gmail.com
}

\begin{abstract}
The experiment was conducted at Greenhouse and experimental garden of Polytechnic LPP Yogyakarta in Wedomartani from March to June 2016. This study aims to know the difference of frequency influence of watering liquid green tea fermentation on the initial growth of rubber plant seedlings. This research use non factorial Random Complete Block Design (RCBD) method, that is fermentation of liquid waste of green tea with 10 $\mathrm{ml} /$ polybag dosage with 3 treatments. The treatment given was control (P0), watering 2 weeks (P2), watering 4 weeks (P4). The giving of liquid organic fertilizer from waste liquid fermented green tea can enhance plant growth include rubber, i.e. plant height, number of leaves, green leaves, heavy wet and dry long \& root plant rubber. At the 2week watering frequency treatments showed the best results than the control treatment and the frequency of watering once every 4 weeks.
\end{abstract}

Keywords: fermentation, tea liquid waste, liquid organic fertilize

\section{PENDAHULUAN}

Limbah cair adalah buangan hasil proses/sisa dari suatu kegiatan yang berwujud cair, kehadirannya pada suatu saat dan tempat tidak dikehendaki lingkungannya karena tidak mempunyai nilai ekonomis sehingga cenderung untuk dibuang. Salah satunya adalah limbah cair teh hijau. Daun teh yang baru dipetik mengandung air $75 \%$ dari berat daun dan sisanya berupa padatan yang terdiri dari bahan organik dan anorganik. Air yang terkandung di daun dikeluarkan melalui proses pelayuan dan pengeringan dalam pengolahan teh hijau di pabrik pengolahan. Limbah cair teh hijau belum dimanfaatkan secara optimal, perlu sentuhan teknologi yang dapat mengubah limbah cair menjadi pupuk organik cair yang bermanfaat (Muningsih et al., 2016).

Limbah cair dapat digunakan sebagai salah satu alternative pupuk organic yang menigkatkan kesuburan tanah dan penambahan unsur hara dalam tanah namun perlu adanya proses fermentasi terlebih dahulu. Fermentasi limbah cair teh hijau dapat menggunkan bioaktifator salah satunya EM-4 sehingga bisa menjadi pupuk organic cair yang berguna sebagai tambahan unsur hara atau pengganti pupuk anorganik. Menurut Purwati (2013), pemberian pupuk organik cair dengan intensitas penyiraman setiap satu mingu, dua minggu, dan tiga minggu sekali pada pembibitan karet yang berumur 30,60 dan 90 HST (hari setelah tanam) memberikan pengaruh nyata dan sangat nyata terhadap rata-rata tinggi tanaman karet. Menurut Pusat Penelitian Karet Sembawa (2002), pada saat pembibitan, penggunaan pupuk yang berasal dari bahan kimia tidak dibenarkan, hal ini disebabkan karena bibit karet sangat rentan terhadap bahan kimia yang dapat menyebabkan bibit mati.

Fermentasi limbah cair teh hijau ini menggunakan bioaktivator EM-4, sehingga limbah cair teh bisa menjadi 
pupuk organik yang mampu memberikan tambahan unsur hara maupun bahan organik dalam tanah yang mudah diserap, dan juga sebagai ZPT alami, sehingga tidak menutup kemungkinan bahwa dengan pemanfaatan limbah cair teh hijau sebagai pupuk organik cair bisa meningkatkan kualitas pertumbuhan bibit karet, mengurangi tingkat kematian bibit, menjadi bahan organik alami yang pada akhirnya mampu meningkatkan produktifitas tanaman dan membantu mengurangi limbah yang berlimpah, sehingga limbah tersebut tidak akan mencemari lingkungan.

Pada penelitian Muningsih dan Susilawardani (2015), hasil analisa limbah cair teh setelah difermentasi 14 hari menunjukkan kandungan C-Organik tinggi dan kandungan hara makro serta mikro yang rendah. Pemanfaatan limbah cair teh hijau yang terfermentasi dengan penambahan starter EM-4 dimaksudkan agar proses fermentasi pembuatan pupuk organik cair berlangsung lebih cepat dan hasil dari fermentasi ini mempunyai kelebihan dibandingkan dengan jenis pupuk lain dalam meningkatkan kesuburan tanah, sehingga tidak menutup kemungkinan bahwa dengan pemanfaatan limbah cair teh hijau sebagai pupuk organik cair bisa meningkatkan kualitas pertumbuhan bibit tanaman karet, mengurangi tingkat kematian bibit, menjadi bahan organik alami yang pada akhirnya mampu meningkatkan produktifitas tanaman dan membantu mengurangi limbah yang berlimpah, sehingga limbah tersebut tidak mencemari lingkungan.

\section{METODE}

Penelitian telah dilaksanakan di Greenhouse dan kebun percobaan Politeknik LPP Yogyakarta di Wedomartani pada bulan Maret sampai bulan Juni tahun 2016. Rancangan lapangan yang digunakan adalah Rancangan Acak Kelompok Lengkap (RAKL) non factorial dengan 3 perlakuan penyiraman air 1 minggu sekali (P0),
Penyiraman 2 minggu sekali (P2), Penyiraman 4 minggu sekali (P4). Masing-masing perlakuan diulang 5 kali. Analisis ragam dengan Anova dilakukan terhadap data pengamatan dari variabel pertumbuhan pada tingkat signifikansi 95\%. Apabila terdapat beda nyata antar perlakuan dilakuan uji lanjutan dengan menggunakan uji jarak berganda Duncan (Duncan's Multiple).

\section{HASIL DAN PEMBAHASAN}

Pada analisis kandungan hasil fermentasi limbah cair teh hijau yang telah dilakukan menunjukkan hampir secara keseluruhan kandungan yang terdapat pada hasil fermentasi limbah cair teh hijau masih berada dibawah standar mutu yang ditetapkan oleh Kementerian Pertanian yang tercantum dalam Permentan No. 70/Permentan/SR.140/10/2011. Dari 9 parameter yang telah di uji hanya terdapat 1 parameter yang sudah masuk kedalam standar mutu yang baik menurut Kementerian Pertanian. Parameter tersebut adalah kandungan C-organik pada hasil fermentasi limbah cair teh hijau. Standar kandungan C-organik pupuk cair organik menurut Kementerian Pertanian adalah minimal 6 $\%$, sedangkan kandungan C-organik pada hasil fermentasi limbah cair teh hijau adalah $6,96 \%$.

Nilai SNI untuk $\mathrm{C} / \mathrm{N}$ ratio pupuk organik cair adalah berkisar antara 15 - 20 (Badan Standar Nasional, 2004), sehingga dapat dikatakan bahwa pupuk organik yang difermantasi tersebut memiliki nilai yang tinggi (29). Nilai $\mathrm{C} / \mathrm{N}$ harus rendah karena jika nilai $\mathrm{C}$ (carbon) lebih tinggi dibandingkan nilai $\mathrm{N}$ maka dikhawatirkan unsur $\mathrm{N}$ akan merombak unsur $\mathrm{C}$ terus menerus dibandingkan tersalurkan ke tanaman.

Kandungan unsur hara dalam POC limbah cair teh hijau menunjukkan bahwa kandungan unsur hara dalam limbah cair teh hijau masih rendah dibandingkan dengan standar teknis 
pupuk cair dari Permentan No.70 tahun 2011. POC termasuk pada pupuk yang slow realese. Namun dengan adanya penambahan POC ini bisa menjadi tambahan unsur hara yang ada di dalam tanah, sehingga memberikan asupan nutrisi yang dibutuhkan oleh tanaman. Semakin banyak unsur hara yang ada di dalam tanah semakin aktif akar tanaman untuk menyerap unsur hara. Menyebabkan dampak positif yaitu pertumbuhan tanaman menjadi lebih baik. Meskipun pupuk organik cair tergolong pupuk slow release atau sering disebut dengan pupuk lepas terkendali (controlled release) (Novizan, 2005).

Tabel 2. Hasil Analisis Limbah Cair Teh Hijau

\begin{tabular}{lcccc}
\hline Parameter & Satuan & $\begin{array}{c}\text { Hasil } \\
\text { Fermentasi } \\
(\mathbf{1 4} \text { Hari })\end{array}$ & Standar mutu* & Harkat* \\
\cline { 2 - 4 } C-Organik & $\%$ & 6.96 & $\min 6$ & Sedang \\
$\mathrm{C} / \mathrm{N}$ rasio & - & 29.00 & $* * 15-20$ & **Tinggi \\
$\mathrm{N}$ total & $\%$ & 0.24 & $3-6$ & Rendah \\
$\mathrm{P}_{2} \mathrm{O}_{5}$ total & $\%$ & 0.07 & $3-6$ & Rendah \\
$\mathrm{K}_{2} \mathrm{O}$ total & $\%$ & 0.65 & $3-6$ & Rendah \\
$\mathrm{S}$ total & $\%$ & 0.03 & - & - \\
$\mathrm{Mg}$ total & $\%$ & 0.04 & - & - \\
Cu total & ppm & 1.73 & $250-5000$ & Rendah \\
Zn total & ppm & 2.74 & $250-5000$ & Rendah \\
\hline Sumber : Laboratorium BPTP Yogyakarta dalam Muningsih dan Susilawardani, 2016 \\
* Permentan No. 70/Permentan/SR.140/10/2011 & & \\
** SNI 19-7030-2004 & \multicolumn{4}{l}{}
\end{tabular}

Pada pengamatan tinggi tanaman, pengaplikasian pupuk organik cair limbah teh hijau berpengaruh nyata pada tinggi tanaman di minggu ke- 4, 5, 6,10 dan minggu ke-13. Tinggi tanaman pada perlakuan P2 (intensitas penyiraman 2 minggu sekali) di umur 6,10, dan 13 minggu setelah tanam memberikan pengaruh yang tertinggi yaitu 42,54 cm; 66,74 cm; dan 89,12 cm sedangkan perlakuan P0 (kontrol) menunjukkan hasil yang terendah. Hal ini terjadi karena pada perlakuakn P2 unsur hara yang diberikan lebih cepat terserap oleh tanaman dan kandungan unsur hara 2 kali lebih banyak dibandingkan pada perlakuan P4.

Tabel 2. Hasil Analisis Limbah Cair Teh Hijau

\begin{tabular}{cccccc}
\hline Parameter & Satuan & $\begin{array}{c}\text { Hasil } \\
\text { Fermentasi }\end{array}$ & $\begin{array}{c}\text { Standar mutu* } \\
\text { (14 Hari) }\end{array}$ & Harkat* \\
\cline { 1 - 1 } \cline { 5 - 6 } C-Organik & $\%$ & 6.96 & min 6 & Sedang \\
C/N rasio & - & 29.00 & $* * 15-20$ & $* *$ Tinggi \\
$\mathrm{N}$ total & $\%$ & 0.24 & $3-6$ & Rendah \\
$\mathrm{P}_{2} \mathrm{O}_{5}$ total & $\%$ & 0.07 & $3-6$ & Rendah \\
$\mathrm{K}_{2} \mathrm{O}$ total & $\%$ & 0.65 & $3-6$ & Rendah \\
$\mathrm{S}$ total & $\%$ & 0.03 & - & - \\
$\mathrm{Mg}$ total & $\%$ & 0.04 & - & - \\
Cu total & ppm & 1.73 & $250-5000$ & Rendah \\
Zn total & ppm & 2.74 & $250-5000$ & Rendah \\
\hline
\end{tabular}

Sumber: Laboratorium BPTP Yogyakarta dalam Muningsih dan Susilawardani, 2016

* Permentan No. 70/Permentan/SR.140/10/2011

** SNI 19-7030-2004 
Menurut Hanolo (1997), pemberian konsentrasi pupuk sedikit dan dilakukan pemupukan secara berkelanjutan lebih memberikan hasil tanaman yang memuaskan daripada pemberian pupuk organik dengan konsentrasi dan waktu yang tepat (1 sampai 2 minggu sekali) secara

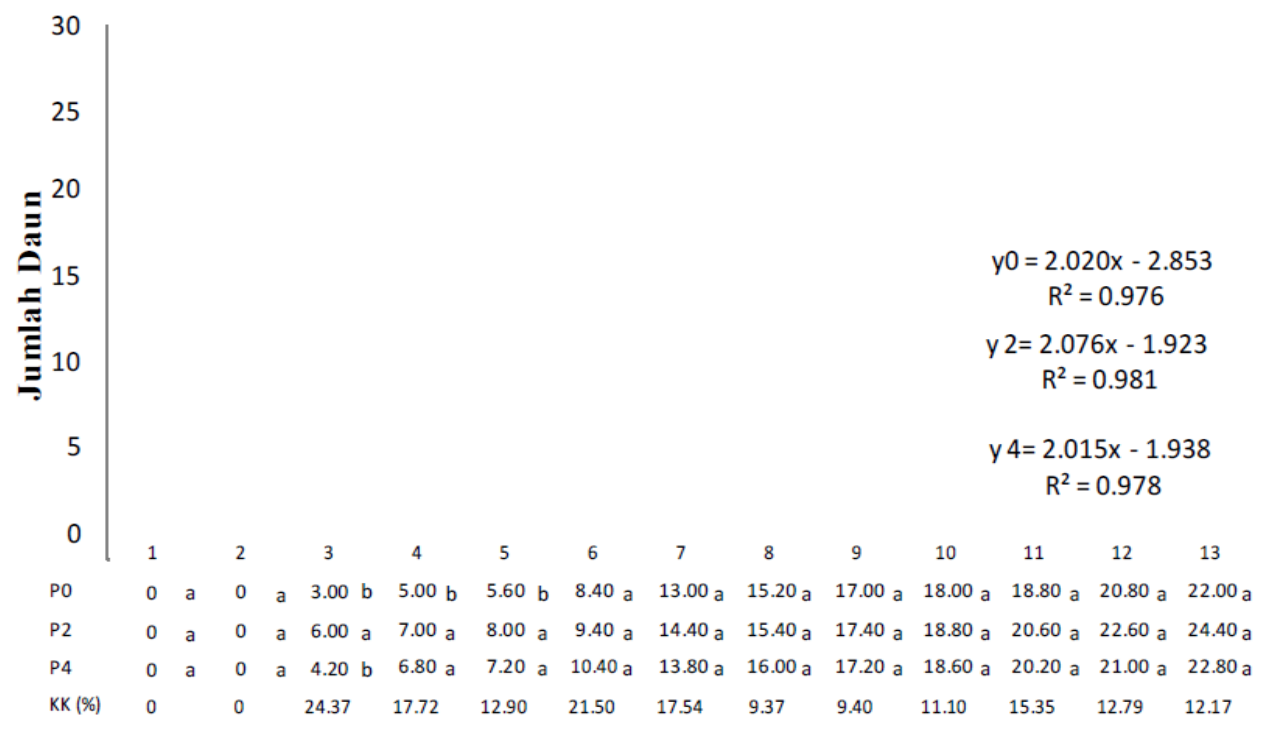

Gambar 1. Pertumbuhan jumlah daun tanaman karet selama 13 minggu

Pengaplikasian pupuk organik cair limbah teh hijau pada minggu ke-3 sampai minggu ke-5 memberikan respon jumlah daun yang berbeda nyata. Namun tidak berpengaruh nyata pada parameter jumlah daun di minggu ke-6 sampai minggu ke-13. Dilihat dari gambar 2 menunjukkan bahwa tanaman yang diberi perlakuan P2 (intensitas penyiraman 2 minggu sekali) memiliki rataan jumlah daun tertinggi dibandingkan dengan perlakuan P0 (kontrol) dan P4 (intensitas penyiraman 4 minggu sekali). Suwandi dan Nurtika (1997), pupuk organik cair akan mempercepat pembentukan daun jika diaplikasikan dalam konsentrasi berkelanjutan lebih memberikan hasil pertumbuhan tanaman yang optimal daripada pemberian POC dengan konsentrasi yang tinggi dengan interval waktu yang cukup lama dalam 1 masa tanam (1 kali) dapat berpengaruh terhadap lambatnya penyerapan unsur hara yang dibutuhkan tanaman. 


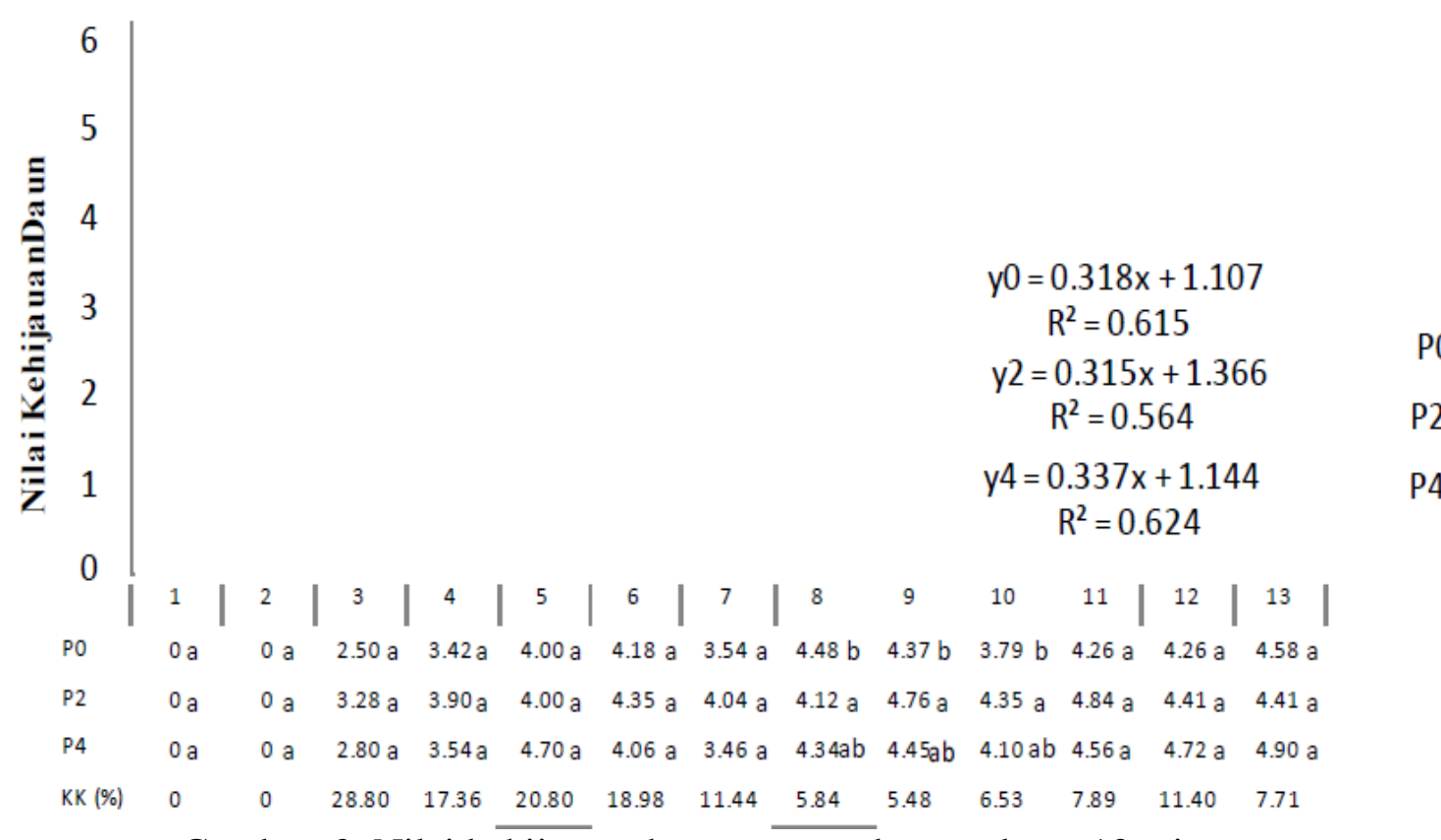

Gambar 2. Nilai kehijauan daun tanaman karet selama 13 minggu

Perbedaan nyata perlakuan P2 dengan P0 dan P4 dapat disebabkan pada perlakuan P2 (intensitas penyiraman 2 minggu sekali) penyiraman hasil pupuk organik cair limbah teh hijau terfermentasi dilakukan lebih sering dibandingkan perlakuan P4 (frekuensi penyiraman 4 minggu sekali). Semakin sering penyiraman hasil fermentasi limbah cair teh hijau maka kandungan unsur hara $\mathrm{N}$ yang terdapat pada tanaman akan semakin tinggi. Kelebihan unsur hara $\mathrm{N}$ pada tanaman dapat meningkatkan kadar klorofil pada tanaman. Hal ini sesuai dengan Mangel dan Kirby (1987) yang menjelaskan bahwa unsur hara $\mathrm{N}$ memegang peranan penting sebagai penyusun klorofil, sehingga daun akan berwarna lebih hijau. Pada minggu ke-5 dan 6 minggu setelah aplikasi pupuk organik cair terdapat pertumbuhan yang lebih tinggi dibandingkan dengan minggu-minggu lainnya baik itu pertumbuhan tinggi tanaman, jumlah daun, maupun nilai kehijaun daun. Hal tersebut disebabkan karna pada minggu ke-5, 6 dan minggu ke 7 setelah tanam, pertumbuhan bibit karet mengalami yang namanya titik puncak tumbuh tanaman, sehingga pada minggu tersebut terdapat berbeda nyata antar setiap variabel pengamatan. Hal tersebut sesuai dengan pendapat Tumpal et al. (2013) bahwa pertumbuhan bibit tanaman karet yang berasal dari biji mengalami titik puncak pada 35-45 hari setelah tanam.

Pengukuran bobot kering batang, daun, dan akar dilakukan pada 13 minggu setelah tanam. Dari pengukuran yang telah dilaksanakan maka didapatkan hasil rataan bobot kering batang, daun dan akar tanaman karet pada perlakuan perbedaan intensitas penyiraman hasil fermentasi limbah cair teh hijau dapat dilihat pada gambar berikut: 


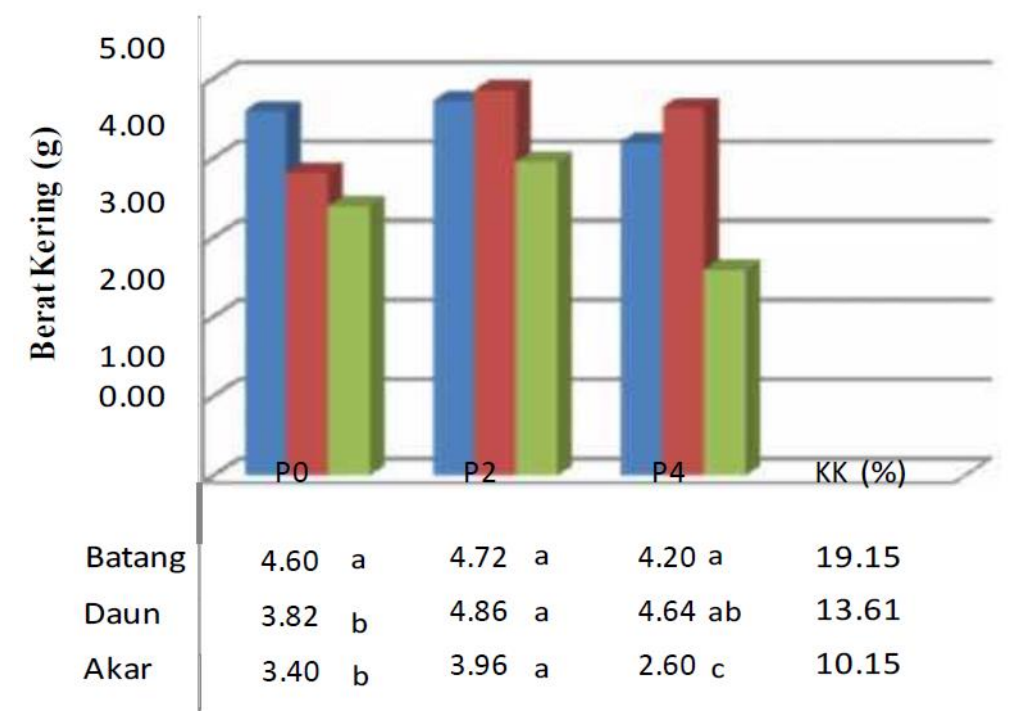

Gambar 3. Rataan berat kering tanaman karet umur 13 minggu

Berdasarkan hasil analisis statistik menunjukkan bahwa pengaplikasian pupuk organik cair limbah teh hijau berpengaruh nyata pada bobot kering daun dan terdapat pengaruh sangat nyata pada bobot kering akar, sedangkan respon bobot kering batang tidak berbeda nyata dibandingkan ke-2 parameter lainnya. Dari ke-3 bobot kering yang di tunjukkan pada gambar 5, perlakuan P2 (intensitas penyiraman 2 minggu sekali) memberikan pengaruh yang tertinggi dibandingkan dengan perlakuan P0 (kontrol) dan P4 (intensitas penyiraman 4 minggu sekali).

Hal ini kemungkinan pupuk organik cair yang diberikan mampu memacu perkembangan jumlah daun, klorofil dan terutama luas daun. Meningkatnya luas daun berarti kemampuan daun untuk menerima dan menyerap cahaya matahari akan lebih tinggi sehingga fotosintat dan akumulasi bahan kering akan lebih tinggi pula pada setiap bobot bagian tanaman. Menurut Wijaya (2010), bahwa penambahan luas daun merupakan efisiensi tiap satuan luas daun melakukan fotosintesis untuk menambah bobot kering tanaman. Selanjutnya dikemukakan bahwa paling sedikit $90 \%$ bahan kering adalah hasil fotosintesis. Faktor lain yang mempengaruhi diantaranya ketersediaan unsur hara bagi tanaman selama pertumbuhan memiliki hubungan erat dengan bobot kering tanaman. Ratna (2002), mengemukakan bahwa apabila unsur hara tersedia dalam keadaan seimbang dapat meningkatkan pertumbuhan vegetatif dan bobot kering tanaman, akan tetapi apabila keadaan unsur hara dalam kondisi yang kurang atau tinggi akan menghasilkan bobot kering yang rendah. Menurut Sumarsono (2007), berat kering mencerminkan akumulasi senyawa organic yang berhasil disintesis tanaman dari senyawa anorganik (air, $\mathrm{CO}_{2}$ dan unsur hara) melalui fotosintesis.

Hasil pengukuran panjang akar pada penelitian tunjukkan pada gambar 5 dibawah ini: 


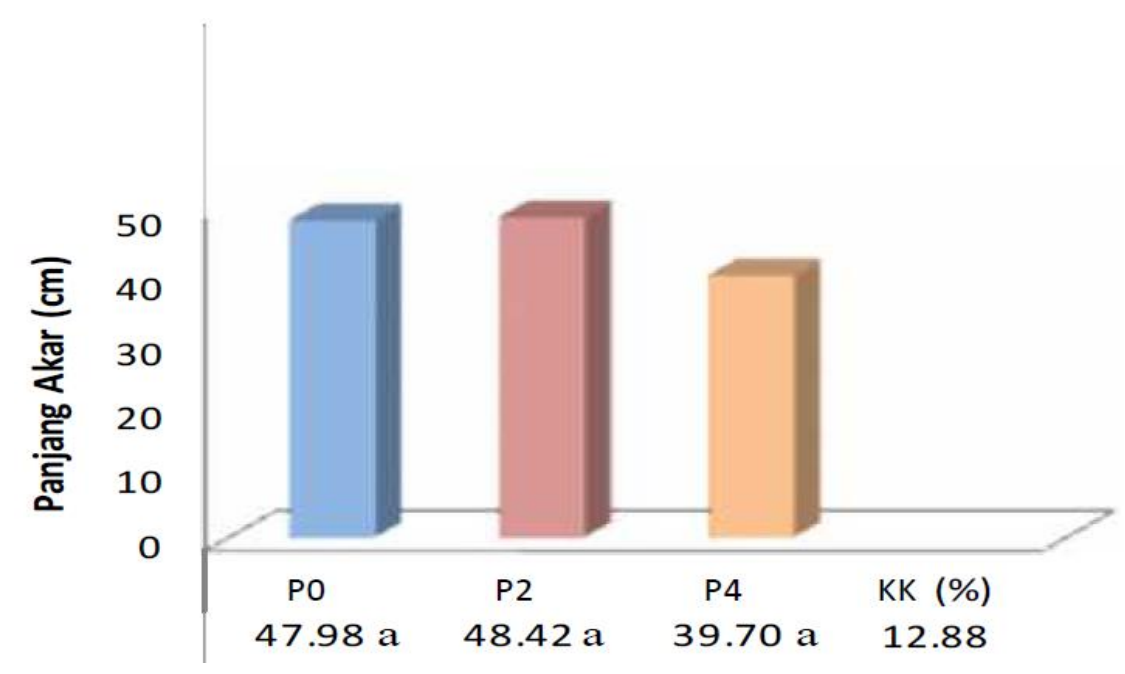

Gambar 5. Rataan panjang akar tanaman karet umur 13 minggu

Berdasarkan hasil perhitungan statsistik yang telah dilakukan maka dapat disimpulkan bahwa tidak terdapat beda nyata antar setiap perlakuan terhadap pertumbuhan panjang akar. Pada perlakuakn P2 (intensitas penyiraman 2 minggu sekali) mengahasilkan panjang akar paling panjang yaitu $48,42 \mathrm{~cm}$, sedangkan pada perlakuan P4 (intensitas penyiraman 4 minggu sekali) menghasilkan panjang akar paling pendek yaitu $39,70 \mathrm{~cm}$. Berdasarkan kandungan unsur hara yang terdapat didalam POC dari limbah cair teh hijau yaitu unsur nitrogen yang berperan dalam pembentukan bagian vegetatif tanaman (akar).

Keadaan tersebut sesuai dengan pendapat Hakim et al. (1986), yang mengatakan bahwa pemberian unsur hara nitrogen yang cukup akan merangsang pertumbuhan akar dan meningkatkan biomassa akar. Maka dari itu pada perlakuan P2 yang lebih sering mendapatkan penyiraman pupuk organik cair (2 minggu sekali) dipastikan unsur hara yang didapat tercukupi bagi akar untuk mengurai dan dijadikan sebagai bahan makan untuk tanaman serta kondisi unsur hara yang tercukupi (pada perlakuan P2) membuat terangsangnya akar untuk melakukan pemanjangan akar.
Nilai SNI untuk $\mathrm{C} / \mathrm{N}$ ratio pupuk organik cair adalah berkisar antara 15-20 (Badan Standar Nasional, 2004), sehingga dapat dikatakan bahwa pupuk organik yang difermantasi tersebut memiliki nilai yang tinggi (29). Nilai $\mathrm{C} / \mathrm{N}$ harus rendah karena jika nilai $\mathrm{C}$ (carbon) lebih tinggi dibandingkan nilai $\mathrm{N}$ maka dikhawatirkan unsur $\mathrm{N}$ akan merombak unsur $\mathrm{C}$ terus menerus dibandingkan tersalurkan ke tanaman.

Kandungan unsur hara dalam POC limbah cair teh hijau menunjukkan bahwa kandungan unsur hara dalam limbah cair teh hijau masih rendah dibandingkan dengan standar teknis pupuk cair dari Permentan No.70 tahun 2011. POC termasuk pada pupuk yang slow realese. Namun dengan adanya penambahan POC ini bisa menjadi tambahan unsur hara yang ada di dalam tanah, sehingga memberikan asupan nutrisi yang dibutuhkan oleh tanaman. Semakin banyak unsur hara yang ada di dalam tanah semakin aktif akar tanaman untuk menyerap unsur hara. Menyebabkan dampak positif yaitu pertumbuhan tanaman menjadi lebih baik. Meskipun pupuk organik cair tergolong pupuk slow release atau sering disebut dengan pupuk lepas terkendali (controlled release) (Novizan, 2005). 
Pada pengamatan tinggi tanaman, pengaplikasian pupuk organik cair limbah teh hijau berpengaruh nyata pada tinggi tanaman di minggu ke- 4 , 5, 6,10 dan minggu ke-13. Tinggi tanaman pada perlakuan P2 (intensitas penyiraman 2 minggu sekali) di umur 6,10, dan 13 minggu setelah tanam memberikan pengaruh yang tertinggi yaitu $42,54 \mathrm{~cm} ; 66,74 \mathrm{~cm}$; dan $89,12 \mathrm{~cm}$ sedangkan perlakuan P0 (kontrol) menunjukkan hasil yang terendah. Hal ini terjadi karena pada perlakuakn P2 unsur hara yang diberikan lebih cepat terserap oleh tanaman dan kandungan unsur hara 2 kali lebih banyak dibandingkan pada perlakuan P4. Menurut Hanolo (1997), pemberian konsentrasi pupuk sedikit dan dilakukan pemupukan secara berkelanjutan lebih memberikan hasil tanaman yang memuaskan daripada pemberian pupuk organik dengan konsentrasi dan waktu yang tepat (1 sampai 2 minggu sekali) secara berkelanjutan lebih memberikan hasil pertumbuhan tanaman yang optimal daripada pemberian POC dengan konsentrasi yang tinggi dengan interval waktu yang cukup lama dalam 1 masa tanam (1 kali) dapat berpengaruh terhadap lambatnya penyerapan unsur hara yang dibutuhkan tanaman.

Perbedaan nyata perlakuan P2 dengan P0 dan P4 dapat disebabkan pada perlakuan P2 (intensitas penyiraman 2 minggu sekali) penyiraman hasil pupuk organik cair limbah teh hijau terfermentasi dilakukan lebih sering dibandingkan perlakuan P4 (frekuensi penyiraman 4 minggu sekali). Semakin sering penyiraman hasil fermentasi limbah cair teh hijau maka kandungan unsur hara $\mathrm{N}$ yang terdapat pada tanaman akan semakin tinggi. Kelebihan unsur hara $\mathrm{N}$ pada tanaman dapat meningkatkan kadar klorofil pada tanaman. Hal ini sesuai dengan Mangel dan Kirby (1987) yang menjelaskan bahwa unsur hara $\mathrm{N}$ memegang peranan penting sebagai penyusun klorofil, sehingga daun akan berwarna lebih hijau. Pada minggu ke-5 dan 6 minggu setelah aplikasi pupuk organik cair terdapat pertumbuhan yang lebih tinggi dibandingkan dengan minggu-minggu lainnya baik itu pertumbuhan tinggi tanaman, jumlah daun, maupun nilai kehijaun daun. Hal tersebut disebabkan karna pada minggu ke-5,6dan minggu ke 7 setelah tanam, pertumbuhan bibit karet mengalami yang namanya titik puncak tumbuh tanaman, sehingga pada minggu tersebut terdapat berbeda nyata antar setiap variabel pengamatan. Hal tersebut sesuai dengan pendapat Tumpal et al., (2013) bahwa pertumbuhan bibit tanaman karet yang berasal dari biji mengalami titik puncak pada $35-45$ hari setelah tanaman.

\section{KESIMPULAN DAN SARAN}

Pemberian pupuk organic cair dari limbah cair teh hijau yang terfermentasi dapat meningkatkan pertumbuhan tanaman karet, meliputi tinggi tanaman, jumlah daun, kehijauan daun, berat basah \& kering serta panjang akar tanaman karet. Pada perlakuan P2 (frekuensi penyiraman 2 minggu sekali) menunjukkan hasil yang paling tinggi dan baik dibanding dengan perlakuan P0 (kontrol) dan P4 (frekuensi penyiraman 4 minggu sekali).

\section{DAFTAR PUSTAKA}

Anonim. 2003. Panduan Teknis
Budidaya

(Vademecum). PT Perkebunan

Nusantara III. Medan. 97 hal.

Anonim, 2008. Panduan Lengkap Karet. Penebar Swadaya. Jakarta.

Anwar C. 2001. Manajemen dan Teknologi Budidaya Karet. Pusat Penelitian Karet. Medan

Direktorat Jendral Perkebunan. 2014. Kriteria Benih Karet Yang Baik Dan Bermutu. http://ditjenbun.pertanian.go.id/ta nhun/berita-253-kriteria-benihkaret-yang-baik-dan- 
bermutu.html. Diakses pada tanggal 12 Maret 2017.

Hakim N, Nyakpa MY, Lubis AM, Nugroho SG. 1986. DasarDasar Ilmu Tanah. Unila. Lampung.

Hanolo W. 1997. Tanggapan tanaman selada dan sawi terhdap dosis dan cara pemberian pupuk cair stimulant. Jurnal Agrotropika 1(1):25-29.

Muningsih R. dan Ciptadi G. Analisa Kandungan Unsur Hara Limbah Cair Teh Hijau Sebagai Bahan Pupuk Organik. Draft Jurnal. Yogyakarta.

Purwati MS. Pertumbuhan Bibit Karet (Havea brasiliensis L.) Asal Okulasi Pada Pemberian Bokashi dan Pupuk Organik Cair Bintang Kuda Laut. Jurnal Agrifor. Volume XII Nomor 1. Maret 2013. Hal 35-43

Rahayu SM dan Nurhayati. 2005. Penggunaan EM-4 dalam Pengomposan Limbah Teh Padat. Jurnal Ilmu Pertanian. Volume 3. Nomor 2. Agustus 2005.

Ratna DI. 2002. Pengaruh Kombinasi Konsentrasi Pupuk Hayati Dengan Pupuk Organik Cair Terhadap Kualitas Dan Kuantitas Hasil Tanaman The (Camellia Sinensis (L.) O. Kuntze) Klon Gambung 4. Ilmu Pertanian 10 (2):17-25.

Rusdiadi H dan Rustam BN. 2015. Pengaruh Konsentrasi Pupuk Organik Cair Nasa Terhadap Pertumbuhan Bibit Tanaman Kakao (Theobroma Cacao L).
Musnamar IE. 2009. Pupuk Organik Cair \& Padat, Pembuatan, Aplikasi. Penebar Swadaya. Jakarta.

Nugroho, Panji. 2009. Pupuk dan Pemupukan. Pustaka Baru Press. Yogyakarta.

Patanga A. dan Yuliarti N. 2016. Pembuatan Aplikasi \& Bisnis Pupuk Organik dari Limbah Pertanian, Peternakan, dan Rumah Tangga. Gramedia Pustaka Utama. Jakarta.

Peraturan Menteri Pertanian. 2011. No.70/Permentan/SR.140/10/201 1 Tentang Pupuk Organik, Pupuk Hayati, dan Pembenah Tanah. Jurnal Agrifarm. Volume 3. Nomor 2. Desember 2014. Hal $53-57$

Setyamidjaja, Djoehana. 1993. Budidaya dan Pengolahan Karet. Kanisius. Yogyakarta.

Sulaeman, Nandang. Dan Wahyudi Raharjo. 1982. Budidaya dan Pengolahan Karet. Lembaga Penelitian Perkebunan. Yogyakarta.

Tumpal H. S., Siregar, dan Irwan Suhendri. 2013. Budi Daya \& Teknologi Karet. Penebar Swadaya. Jakarta.

Wulandari, A.S, I. Mansur, dan H. Sugiarti. 2011. Pengaruh Pemberian Kompos Batang Pisang terhadap Pertumbuhan Semai Jabon (Anthocephalus cadamba Miq.). Fakultas Kehutanan Institut Pertanian Bogor. Jurnal Silvikultur Tropika. Vol. 03 No. 01, Hal. 7881. 